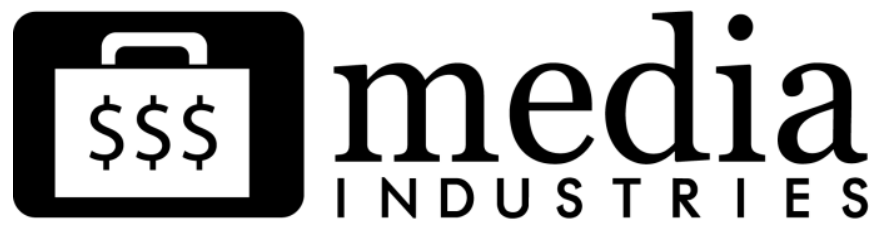

\section{Dirt Research for Media Industries}

\author{
Charles R. Acland 1 \\ Concordia University \\ c.acland $[\mathrm{AT}]$ concordia.ca
}

\begin{abstract}
:
Media industries scholarship takes for granted that media industries produce media commodities. The most prominent approaches in this scholarship are production culture studies focusing on media work contexts, political economic analysis that prioritizes ownership, and policy studies attending to regulatory structures. But as the major contributions of cultural theory instruct us, media produce far more than commodities. Even economist Harold Innis proposed that a study of the deep, resource-based infrastructure of major industrial sectors was essential to any full accounting of economic life. This essay addresses how Innis's concept of "dirt" research helps us expand the boundaries of media industries studies. It shows that the concept simultaneously asks us to take stock of deep economic relations, as well as the shifting cultural formations that result. Media industries scholarship, in this way, might just be able to navigate away from a creeping administrative pull toward analyses that help "improve" dominant institutional and competitive operations, and instead encompass a wider epistemological frame that will denaturalize the priorities set by reigning media corporations.
\end{abstract}

Keywords: Convergence, Cultural Studies, Distribution, Economics, Social Media

As the research ferment that falls under the general heading of "media industries" continues to expand, it is curious how taken for granted that domain can appear to be. But what are these "media industries" of which we speak? One thinks of large-scale coordinated production and distribution activity oriented toward commercial cultural production. The plural "industries" mirrors the plural "media," and together as a term immediately reference the big culture businesses of motion pictures, broadcasting, music, publishing, cable, and social media. Even the industry studies of subcultural, micro-organizational, and non-dominant media activities still, by and large, articulate to these grand domains. Unlike the more singularly inflected "culture industry" defined by Adorno and company, ${ }^{2}$ where an array of productive mechanisms coordinate to produce mass capitalist societies and subjects, "media industries" tries to capture more asynchronous endeavors, ones that might in fact be in competition with one another. Nonetheless, with the settlement of transmedia as a major shared conceptual umbrella, "media industries" today has come to reference a field with a degree of coherence, 
one into which "convergence" smuggles an idea of symbiosis among media forms. In this way, we write and think about media corporations, producers of media commodities, and harvesters of profit from expressive and communicative materials as sharing core features, agendas, audiences, practices, and technologies. As a result, the appreciation of variance and multiplicity in media is dampened.

The work of maintaining plurality and provisionality in our critical engagements produces another demand. As someone who has insisted on the necessity of understanding the multiplicity of the film industry, and of seeing it as entwined with a range of media and other businesses, I still confront the frustrating need to reference something called "the film industry," with all the implied coherence I want to refute. The plural in writing can come across as a forced and clunky stylistic demand, one that draws inordinate attention to itself and slows down progress to the point one actually wishes to make. It's the writerly equivalent of trudging in rain boots on a sunny day.

But there it is. We just seem to know what we are talking about when we evoke "media industry" in its singular or plural form, and it suggests a coherence that may in fact be lacking. Of course, media industries produce far more than media commodities. First, study of publicly funded and mandated cultural institutions is one of the more underdeveloped domains of American media industries research. Additionally, as the major contributions of cultural theory instruct us, cultural enterprises of all sorts produce audiences, fans, artists, conversations, understandings, spaces, occasions, moods, communities, differences, divisions, myths, falsehoods, and so on. The more regularized patterns of activity settle provisionally into cultural formations, consisting of localized waves of activity, styles, and priorities. Cultural formations are provisional features of cultural life. They bear a degree of informality that makes identifying them challenging. But they provoke and can act as agents of change. Though these are just some general components of cultural production, and there are many others, to ignore them would seriously wound our ability to respond to, and comment upon in a meaningful fashion, the conditions of our time.

Media industries have long been exemplars of post-Fordist, "disorganized" capitalism, with their flexible operations, short-term contract labor, and high geographic mobility. The media industries are, in many ways, the neoliberal vanguard of advanced digital capitalism. The concomitant massification of large media-focused corporations and the multiplication of small media businesses is a situation that has given fuel to the tales of start-up Davids slinging killer apps at generally receptive old media Goliaths, and being rewarded with unimaginable riches. Indeed, Malcolm Gladwell's newest bestseller is yet another contribution to the mythological advantages of being disadvantaged. ${ }^{3}$ This ideological mystification, clouding the concrete production of material advantage with the foggy reverie of magical bastion-storming, resonates with a broad embrace of individual, promotional, and aspirational narratives of success. Gina Neff's Venture Labor offers detailed myth-busting about these narratives, documenting the actual precarious work conditions in the high-tech industry. 4

We are in the midst of the full flourishing of the enterprise society, which Michel Foucault identified as a truly distinctive feature of neoliberal society, more so than tropes of spectacle or supermarket. ${ }^{5}$ Nowhere is this more apparent than in the media industries. The thrill of the fast buck made on the virtual capitalization of personal data, which characterizes many of the most visible digital media start-ups in recent years, has sparked a new celebration of "idols of production." Leo Lowenthal coined this characteristic in 1944, noting that it had been overtaken 
as a theme of popular biographical articles by "idols of consumption." 6 Well, the attention paid to Jobs, Zuckerberg, Gates, and others of that moneyed ilk suggests that those idols of production, though of a decidedly twenty-first century digital kind, have returned. The difference this time around is that enthusiasm for YouTube, Facebook, Google, LinkedIn, and Twitter springs from the possibility that their wares will engender some other new enterprise that in turn will rocket to riches. The social media wonder is that they provide platforms - the software infrastructure-for success elsewhere. Social media have leveraged a new tycoon culture; namely, a limitless promise of more tycoons. Parts of the media industries are converging to become an enterprise industry.

I present these claims, partial as they are, to mark some of the cultural dimensions that might be overlooked by research more closely attentive to strictly defined industrial operations and organizations. But even on a narrowly industrial terrain, there are forces and histories that often remain untapped in analysis. Currently, the most prominent scholarly approaches on the critical scene are production culture studies focusing on media work contexts, political economic analysis prioritizing ownership and commodities, and policy studies attending to regulatory structures. To unsettle our view of what we study when we study "media industries," the innovations of economist and historian Harold Innis can be instructive. In the 1930s and 1940s, Innis proposed that a study of the resource-based infrastructure of major industrial sectors was essential to any full accounting and understanding of economic life. This deep infrastructural analysis involved comparative historical study through archival research that ran the gamut of documentation, including secondary historical accounts, government papers, corporate records, and ephemera. Additionally, Innis insisted upon extensive field research, and in a self-deprecating manner called himself a "dirt economist." By "dirt" research, Innis meant a form of witnessing and experiencing the sites, routes, venues, and operations of industrial production, refinement, and transport. To do this, he travelled extraordinary distances through remote regions, doing so by rail, boat, and canoe. This "dirt" research was not conventional ethnographic writing, but rather a form of attentiveness to the minute and localized aspects of extraction, transportation, refinement, and distribution stages of the economy, whether at moments of ascension, prosperity, or decline. ${ }^{7}$

Innis's "dirt" research helps us expand the boundaries of media industries studies to encompass some of the foundational resource requirements and implications of the production and distribution of media works. If we follow the traces of industrial impacts backward, we end up at the level of minerals, the manufacture of basic materials, and the resource economies that underlie the production and circulation of goods. So much of Innis's work on the history of communication focused on paper, its manufacture, its distinction from other writing materials like papyrus and manuscript, and its role in constructing monopolies of economy and knowledge. Today, he would say our media environment requires an economic history of plastic, microchips, processing units, and electrical power.

Via Innis, we've had a way to understand that the newspaper and book trade was also a lumber and railroad industry. A model of economic depth would, for example, capture film as a chemical and electronics industry, radio as a physics industry, television as a mining industry, and the Internet as an electricity industry. No media industry operates without an elaborate distribution network specifically designed for a medium's particular technological contours, which means that the speed of travel for goods and materials plays prominently in the state of industrial endeavors. In fact, this is a defining characteristic for a media industry: Of all the possible forms of mediation one might imagine, it is this distributive feature that typifies highly 
developed industrialization of a medium. At one level, media commodities are but a surface manifestation of a deep structure of materials and their movement. Our analytical capabilities would be impoverished if they only charted the topsoil and ignored the geological layers beneath. Pursuing the dirt and depth of cultural economies should not dissolve medium specificity, but should help us conceptualize and understand the full systemic entwinement of our media objects with resource economies. This opens up the historical contingencies of industrial expansion, such that a media industry can only develop in a relative fashion with the resource industries it relies upon. ${ }^{8}$

As I read so much invigorating and inspiring work that operates in the orbit of media industries research, some of it veers into the cozy territory occupied by Paul Lazarsfeld's definition of administrative research, "carried through in the service of some kind of administrative agency of public or private character." 9 Some accounts of industrial relations and activities inadvertently naturalize "the industry" as a timeless and essential beast. Yes, media industries are crucial points of focus for our critical imagination if only due to their dominant presence in daily life. But we must continue to seek wider epistemological frames for investigating, and keeping tabs on, the enterprises that spring from the pool of media activities and ambitions, frames that trouble us to see the dirt and depth of economic systems and the shifting tendencies in cultural formations that result.

${ }^{1}$ Charles R. Acland is Professor and Concordia University Research Chair in Communication Studies at Concordia University, Montreal. His books include Screen Traffic: Movies, Multiplexes, and Global Culture (2003), Swift Viewing: The Popular Life of Subliminal Influence (2012), and Useful Cinema (2011), co-edited with Haidee Wasson (all Duke University Press).

2 Horkheimer, Max, and Theodor W. Adorno, Dialectic of Enlightenment: Philosophical Fragments, (1944; reprint, Stanford, CA: Stanford University Press, 2002).

3 Malcolm Gladwell, David and Goliath: Underdogs, Misfits, and the Art of Battling Giants (New York: Little, Brown and Company, 2013).

4 Gina Neff, Venture Labor: Work and the Burden of Risk in Innovation Industries (Cambridge: MIT Press, 2012).

5 Michel Foucault, The Birth of Biopolitics: Lectures at the Collège de France, 1978-1979 (New York: Picador, 2008), 251.

6 Leo Lowenthal, "The Triumph of Mass Idols," in Literature, Popular Culture, and Society (Englewood Cliffs, NJ: Prentice-Hall, 1961 [1944]), 109-136.

7 The fullest account of this aspect of Innis's work appears in the recent release William J. Buxton, ed., Harold Innis and the North: Appraisals and Contestations (Montreal/Kingston: McGill-Queen's University Press, 2013).

8 The work of Lisa Parks and Nicole Starosielski is offering such advances, e.g. Signal Traffic: Critical Studies of Media Infrastructures (Urbana: University of Illinois Press, forthcoming).

9 Paul Lazarsfeld, "Remarks on Administrative and Critical Communication Research," Studies in Philosophy and Social Science 9, no. 1 (1941): 8. 


\section{Bibliography}

Buxton, William J., editor. Harold Innis and the North: Appraisals and Contestations. Montreal/Kingston: McGill-Queen's University Press, 2013.

Foucault, Michel. The Birth of Biopolitics: Lectures at the Collège de France, 1978-1979. New York: Picador, 2008.

Horkheimer, Max, and Theodor W. Adorno. Dialectic of Enlightenment: Philosophical Fragments. 1944: reprint, ,Stanford, CA: Stanford University Press, 2002.

Gladwell, Malcolm. David and Goliath: Underdogs, Misfits, and the Art of Battling Giants. New York: Little, Brown and Company, 2013.

Lazarsfeld, Paul. "Remarks on Administrative and Critical Communication Research." Studies in Philosophy and Social Science 9, no. 1 (1941): 2-16.

Lowenthal, Leo. "The Triumph of Mass Idols." In Literature, Popular Culture, and Society. Englewood Cliffs, NJ: Prentice-Hall, 1961 [1944], 109-136.

Neff, Gina. Venture Labor: Work and the Burden of Risk in Innovation Industries. Cambridge: MIT Press, 2012.

Parks, Lisa and Nicole Starosielski. Signal Traffic: Critical Studies of Media Infrastuctures. Urbana: University of Illinois Press, forthcoming.

\section{$(\mathrm{Cc}) \mathrm{EY}-\mathrm{NC}-\mathrm{ND}$}

Copyright (C) 2014 (Charles Acland). Media Industries is and open-access, peer-reviewed, online academic journal. As such, we aim to participate in the open exchange of information. This work is licensed under a Creative Commons Attribution Noncommercial No Derivatives (by-nc-nd) License. Under this license, this work is available for sharing and noncommercial distribution provided the appropriate attribution is given. 